\title{
Mobilising African music: how mobile telecommunications and technology firms are transforming African music sectors
}

\section{Christiaan De Beukelaer \& Andrew J. Eisenberg}

To cite this article: Christiaan De Beukelaer \& Andrew J. Eisenberg (2018): Mobilising African music: how mobile telecommunications and technology firms are transforming African music sectors, Journal of African Cultural Studies, DOI: 10.1080/13696815.2018.1546569

To link to this article: https://doi.org/10.1080/13696815.2018.1546569

+ View supplementary material $₫$

曲 Published online: 26 Nov 2018.

Submit your article to this journal $2 \pi$

View Crossmark data $₫$ 


\title{
Mobilising African music: how mobile telecommunications and technology firms are transforming African music sectors
}

\author{
Christiaan De Beukelaer (1D ${ }^{\mathrm{a}}$ and Andrew J. Eisenberg (1D) \\ ${ }^{a}$ School of Culture and Communication, University of Melbourne, Melbourne, Australia; ${ }^{b}$ Division of Arts and \\ Humanities, New York University Abu Dhabi, United Arab Emirates
}

\begin{abstract}
This paper explores the role of mobile telecommunication and technology firms (MTTs) in the distribution of recorded music in Ghana and Kenya. These countries both have vibrant music markets with weak formal distribution networks. Limited enforcement of copyright regimes and weak market regulation created new entrepreneurial business models. While 'big tech' dominates this space elsewhere, in African contexts the main players are mobile service providers (e.g. MTN, Vodafone, Tigo) and digital content firms (e.g. Liberty Afrika, MTech, Cellulant). These transnational players cater to fast-growing consumer markets that do not have easy access to major music distribution platforms such as iTunes and Spotify (which tend to provide very limited access to 'local' content, in any case). Despite their particular and increasingly significant roles, very little empirical attention has been paid to the activities of mobile telecommunication and technology firms (MTTs) in music sectors. This paper takes stock of why and how MTTs have entered into the business of recorded music distribution in Ghana and Kenya, and assesses the ramifications of their entry for the music sectors in these and other African countries as part of broader global shifts in the production, distribution and marketing of recorded music.
\end{abstract}

\section{KEYWORDS}

Music industry; music distribution; piracy; mobile phones; telecoms; mcommerce; Ghana; Kenya

\section{Introduction}

In 2012, a young Nigerian man named Ikechukwu Anoke emerged as a new powerbroker in Kenyan popular music. Having helped to launch hitmaking pop group Camp Mulla, he was busy signing management contracts with some of the country's top artists. Given the success of Nigerian popular music in the second decade of the twenty-first century, it is not surprising that a Nigerian would emerge as an influential figure in Kenyan music at this moment. What is surprising, however, is that this Nigerian would have arrived in Kenya with little to no prior experience in music production or promotion. Anoke had moved to Kenya to head up the East African subsidiary of a Nigerian mobile technology firm. This, it turned out, was enough to place him at the centre of the Kenyan music sector.

CONTACT Christiaan De Beukelaer Christiaan.DeBeukelaer@unimelb.edu.au $\Theta$ School of Culture and Communication, University of Melbourne, Melbourne, Australia

(4) Supplemental data for this article can be accessed https://doi.org/10.1080/13696815.2018.1546569. 
Anoke's transition from mobile telecommunications executive to music mogul is one of many stories that speak to a large-scale transformation in African 'musical capitalism' (Born $2013,51)$. This article explores the institutional backdrop against which these stories are playing out. Over the past decade, the business of music in Africa has become increasingly bound up with mobile telecommunications. As music sectors in western (and some Asian) countries are being reshaped by the rising influence of decentralised networks and online systems dominated by GAFA (Google, Apple, Facebook, and Amazon), African music sectors are experiencing a different, but no less disruptive and transformative, moment of 'transectorial innovation' (Jenkins 2008; Morris 2015; Théberge 1997), due to the entrance of local and international mobile telecommunications and technology firms (MTTs). In this article, we explore how African music sectors have become entangled with what we refer to as MTT sectors. We draw our data from Ghana and Kenya, for the practical reason that each of us has undertaken extended research on the economics of music in one of these countries (Christiaan de Beukelaer in Ghana, Andrew J. Eisenberg in Kenya). The striking similarities that emerged in our informal conversations about our respective research prompted us to undertake the more thoroughgoing and diagnostic exploration of the role of MTTs in African music sectors that we present in this paper.

The terms music sector and $M T T$ sector are by no means transparent; however, we refrain from defining them a priori, as our aim is precisely to develop an understanding of African music and MTT sectors through an analysis of their transectorial interactions. These interactions, we suggest, are increasingly integral to each of them. Our approach in this respect is broadly 'relational'. In Latour's language, we 'assemble', rather than assume, totalities by tracing the relations and mediations that comprise them (Latour 2005). But it grows less from an engagement with theoretical works of the 'relational turn' than from a methodological focus on the stories of the individual and collective actors who navigate and remake institutional structures. We locate our work within the emerging field of 'economic ethnomusicology', which employs ethnographic and other qualitative methods to explore the economic relations in and around musical practice (Morcom and Neveling 2015; Perullo 2011; Taylor 2012, 2015). In particular, we draw inspiration from Perullo's (2011) approach of piecing together the various institutions and practices of a 'music economy' (as he calls it) by describing the 'creative practices' that serve to enact them. Our work here is only ethnographic in a limited sense, however. We make use of data from ethnographic fieldwork; but since our aim to map the new institutional terrain that has emerged from the intersection of music and mobile telephony in Africa, our analysis remains above the ground level where the ethnographic rubber meets the road. We leave it to future work, by ourselves and others, to engage more closely with the experiences and perspectives of the actors that animate this new terrain.

In addition to economic ethnomusicology, we draw perspectives from the literature on music, media, and cultural industries (Hesmondhalgh 2013; Meier 2016; Morris 2015; Sterne 2012). The natural point of articulation for these literatures is the 'digital music commodity', which Morris (2015) defines as 'a particular combination of data and sound that exists as an entity in and of itself for sale or acquisition in online outlets via computers or other digital portable devices' $(2015,2)$. The paradigmatic form(at) of digital music commodity is the MP3, understood as a contained and transportable music file encoded with the MPEG Layer 3 compression algorithm (Sterne 2012). ${ }^{1}$ But we introduce other forms here, as well - in particular, the ringback tone - whose import in African 
contexts suggests that the MP3 does not have the same global dominance it once did (Sterne 2012, 198).

Morris (2015) stresses the novel socio-material relations that prevail in the digital music commodity, and how they have transformed the ways in which music is commodified and experienced. 'Rather than a dematerialisation', he argues, 'digital music is a rematerialized commodity, one whose materials bring new sources of value for listeners, companies, and music itself' (Morris 2015, 14 emphasis in original). The shift from tangible objects as music carriers to largely intangible 'files' in the digital context has not removed, but rather 'retuned' the music commodity's previously defining physical manifestation into a more mobile and versatile digital formal that still relies on an ecology of playback devices and other tangible infrastructures. We draw on Morris's insight to begin to think about what appears to be a revolution in musical capitalism in Africa and other parts of the Global South - notably India (Beaster-Jones 2014), South Korea (Lee 2012), and Bolivia (Stobart 2010) - whereby the ways music is exchanged and experienced are shaped by digital music commodities that constitute and are constituted by the convergence of music and mobile telecommunications.

We proceed by mapping what we call the dynamic alignments of the music and MTT sectors in Ghana and Kenya, by which we mean the sometimes fleeting, sometimes lasting situations in which the two sectors come to share a set of institutional structures and strategies. Our analysis reveals a number of ways in which African music sectors have been transformed by these dynamic alignments. At the same time, it suggests that the convergence of the music and MTT sectors in African countries has perpetuated, rather than challenged, the political economy of music. Whether controlled by major record labels or MTT firms, it seems, African music sectors retain their oligonomic character: intermediaries (labels, distributors, promoters, media outlets, etc.) still act as an oligopoly ('when a few sellers control a particular market') towards audiences and an oligopsony ('a market in which there are many sellers, but few buyers') towards musicians (Bishop 2005, 445), tempering the potential for music creators to act on existing power structures.

The remainder of this article is organised in four sections. The first two offer preliminary discussions of the music and MTT sectors. We then explore how the convergence of these sectors manifests. Finally, before concluding, we discuss how economic value is extracted from music in this new context and by whom.

\section{Music}

When we speak of African music sectors, we mean spaces of economic activity oriented around creating value from music genres that primarily fall within the realm of 'popular music'. In Ghana, Kenya, and a number of other African countries, this realm expanded at the turn of the millennium, as media liberalisation 'created a new space, first for access to foreign music then for new local music' (Eisenberg Forthcoming; Grätz 2013; Shipley 2012,13). New genres burst on the scene, and now exist alongside older genres (e.g. highlife in Ghana and benga in Kenya) as well as genres that combine elements of old and new (e.g. hiplife in Ghana and neo-benga in Kenya). For the most part, we do not deal with the aesthetic formations - the styles and genres - that inhere in African music sectors. Though we engage in dialogue with scholarship that brings musicological perspectives into the analysis of music sectors (Eisenberg Forthcoming; Perullo 2011; 
Shipley 2013), we bracket the aesthetic here in order to focus more tightly on institutional dynamics.

African music sectors are extraordinarily diverse. While some key characteristics (high risk, olignomic structure, non-rivalrous [digital] goods, etc.) are broadly shared among them, the local 'path-dependency' of production, distribution, and consumption of music has spawned a wide variety of configurations of key players and business models (De Beukelaer 2015). Analysing African music sectors thus necessitates a grounded approach that attends to transactions and regimes of value that do not easily align with a. priori conceptions of how the sector is (or should be) organised.

As mentioned above, we draw inspiration from Perullo's (2011) emphasis on multifarious 'creative practices' in his study of the Tanzanian 'music economy'. Perullo explains that he developed his approach in response to the obvious shortcomings of analyses that assume African music sectors to be merely underdeveloped versions of Western music sectors and therefore seek 'to understand the way music is being produced, sold, and purchased [by looking] for record companies, performing rights organizations, and large numbers of albums sold' (Perullo 2011, xv). Such factors, Perullo's work demonstrates, may well be absent or barely present in an otherwise dynamic African music sector (see also De Beukelaer and Spence 2019). Where we depart from Perullo is in our decision not to adopt his key term 'music economy', which makes an awkward fit with another term we find extremely helpful: 'transectoriality'. In part, this is a purely 'editorial' decision, designed to enhance the clarity of our prose (transectoriality, after all, refers to 'sectors', not 'economies'). But we also suggest that the totalising connotation of 'economy' may lead us away from essential questions of musical capitalism in Africa that the concept of transectoriality opens up, such as questions about local African responses to the processes of media 'convergence' (Jenkins 2008) that have been spurred by the advent of the 'digital music commodity' (Morris 2015).

To the extent that African music sectors resemble one another, it is largely because they share a set of challenges that negatively affect the ability of music creators to generate revenue from their creations. These include, primarily, weak networks of recorded music distribution, due to a combination of the slow adoption of digital distribution methods by incumbents and the disruptive effects of digital innovations - effects that are exacerbated by the agility of unauthorised distributors or 'pirates' (De Beukelaer 2015; Eckstein and Schwarz 2014; Röschenthaler and Diawara 2016) - and a lack of effectiveness and transparency among collective management organisations (CMOs), which has meant that airplay (often secured through payola) does not necessarily result in royalties payments or album sales (Perullo and Eisenberg 2014; Street, Laing, and Schroff 2016).

These challenges collude to situate three broad sets of activities at the centre of most, if not all, African music sectors: live performance, music recording, and celebrity marketing. The last of these comprises activities through which creative music workers extract value from artists' fame through endorsement deals, brand marketing and 'ambassadorship', and product or service 'launches' (Pier 2015; Shipley 2013). These sets of activities sit in a tight, mutually reinforcing relationship: poor returns on recorded music lead to a greater emphasis in live performance and celebrity marketing, both of which provide new reasons for remaining in the business of being a 'recording artist' (De Beukelaer 2016; Holt 2010; Skinner 2014). Our analysis of the activities of MTTs in the music 
sectors of Kenya and Ghana homes in on this triad of live performance, music recording, and celebrity marketing.

\section{MTTs}

African Mobile Telecommunications and Technology Sectors (MTTs) comprise three types of organisations: 1) mobile service providers (also commonly referred to as 'mobile network providers', 'mobile service operators' or 'mobile telecoms'), 2) digital content firms (including digital content intermediaries, variably known as 'premium rate service providers' or 'content service providers', as well as operators of platforms for mobile music sales and services), and 3) mobile hardware manufacturers. Our aim in this section is to sketch the diversity of these actors and their activities in Ghana and Kenya, with special attention to how the activities orient the actors toward local music sectors.

\section{Mobile service providers}

The sheer reach of mobile telecommunications in Ghana and Kenya is one of the primary conditions for the convergence of the music and MTT sectors in these countries. As detailed in Supplement 1, mobile service providers connect vast swaths of the populations of Ghana and Kenya, and internet use has ballooned in these countries within the past decade as a result. ${ }^{2}$ Given the weakness of the distribution networks for recorded music, this situation represents an obvious opportunity for music creators. Bob Collymore, CEO of Kenya's largest mobile service provider Safaricom, put the matter plainly, if condescendingly, in a 2011 interview: 'Importantly for these kids [young music artists], not only do we provide a platform, we provide money for them so they can sell. We provide a platform with 18 million, 17 million customers, so they can sell their music' (BalancingActAfrica 2011).

Meanwhile, the competitive environment for mobile voice and text communication has driven mobile service providers to embrace the sale of data and so-called 'value added services', both of which create openings for dynamic alignments of the music and MTT sectors, as detailed below. Data use, both in terms of number of subscribers and the amount of data consumed, forms a primary growth segment for mobile service providers, resulting in vast markets for telecom operators that sell data bundles (ranging on average from 100 megabytes to 5 gigabytes). Remaining potential for further market penetration in this area promises to drive further competition and innovation (see Supplement 1, Tables 4 and 5). Value added services form a less significant growth segment for mobile service providers, with the notable exception of mobile money transfer solutions such as Safaricom's M-Pesa system, which sees billions of dollars in transfers every quarter (see Supplement 1 , Table 6).

The advent of mobile money not only enables telecoms to play a leading role in digital transactions. It also transforms the mobile phone into a common tool for everyday commerce. This holds great significance for the marketing of recorded music via mobile networks, and is likely part of the reason for the remarkable dynamism of commercial music distribution via mobile telecommunications networks, or music m-commerce, in Kenya (Eisenberg 2012). Data on mobile money in Ghana are not easily available, but it is clear these systems have seen slower uptake there than in Kenya; and the same comparison can be made with respect to music m-commerce in the two countries. 
There are four common forms of music m-commerce, in Africa and globally, each built around the sale or, more commonly, rental of one of four types of digital music commodity: the ringtone, the ringback tone, the music download, and the music stream (see Table 1; cf. Lee 2012, 249). Within MTT sectors, and in the experience of mobile phone users, each form is generally conceived of as a 'service' in which music is 'delivered' (rather than 'sold') in a particular format. As such, music m-commerce benefits mobile service providers by increasing data use, while also generating revenue for multiple parties through the sale of music 'content'. It also has the added potential benefit of bolstering brand loyalty - which is no small matter in a context in which client base growth is slowing and profit margins are decreasing.

Mobile service providers in Ghana and Kenya have not been quiet about their expanding role in local music distribution. On the contrary, they have worked to position themselves as patrons of local music sectors, by sponsoring music awards shows and music industry expos. Such activities, which we categorise as industry patronage (see below), are essentially special forms of brand marketing that also have as their aim the development of the local music 'content' industries that feed the growth in m-commerce.

\section{Digital content firms}

Music m-commerce has opened a space for new forms of intermediation that have been taken up by an array of new and previously existing firms. These digital content firms fall into two types, digital content intermediaries and third-party $m$-commerce platforms. The former license music 'content' and aggregate it for mobile service providers. In many cases, a digital content intermediary also - perhaps even primarily - operates in other areas outside of music, offering 'digital solutions' to large corporations (including, but not limited to, mobile service providers). For example, Cellulant, a major Kenyan digital content intermediary that has recently expanded operations to seven other African countries, describes itself on its homepage as 'a mobile commerce company operating a payments ecosystem connecting financial sector customers, Mobile service providers and businesses to their increasingly mobile consumers' (Cellulant Corporation n.d.).

Table 1. Mobile music services.

\begin{tabular}{ll}
\hline Service & \multicolumn{1}{c}{ Description of Service } \\
\hline Ringtone & $\begin{array}{c}\text { A service offered by mobile service providers and third-party digital content firms that allows a user to } \\
\text { download polyphonic or 'realtone' ringtones to her phone. The user incurs a one-off cost when } \\
\text { downloading the ringtone, often charged as a premium SMS charge (see Gopinath 2013). }\end{array}$ \\
Ringback tone & $\begin{array}{c}\text { A service offered by mobile service providers, typically in partnership with digital content intermediaries, } \\
\text { that allows a user to select an audio file (generally a popular song) to replace the standard signal tone } \\
\text { set by the operator software when another user calls her. The user incurs a one-off or recurring fee for } \\
\text { this service. (See reference to Safaricom's Skiza service below.) }\end{array}$ \\
Music & A service offered by mobile service providers and third-party digital content firms that allows a user to \\
download & download music files (typically encoded in MP3 format) directly to her phone. The user incurs a one-off \\
& cost when downloading a song, often charged as a premium SMS charge. (See Musibuy and Mdundo \\
busic & A selow.) \\
streaming & stream music from a selected catalogue for a recurring fee. This type of service is often offered on a \\
'freemium' basis: that is, at no charge to the user when interspersed with commercial advertisements. \\
Mobile service providers often offer streaming packages, where data is included in the music \\
subscription or music streaming is included in data packages. (See Spinlet, Kleek, and Tigo Music \\
below.)
\end{tabular}


African digital content intermediaries have shown great flexibility not only in how they have across multiple sectors, but also in how they have worked within the music sector. This is especially true in Kenya, where the phenomenal success of Safaricom's Skiza Tunes ringback tone service has spawned what might reasonably be called a digital content industry. Among the dozen or so digital content intermediaries that have worked with Safaricom to supply content for Skiza (see Table 2 for a list at the time of writing), two - Bernsoft and MTech - have leveraged their footholds in the music sector to enter into an array of business arrangements with music creators beyond licensing their works. Bernsoft initiated an expansion of its music-related activities in 2011 by positioning itself as a producer of music content (including music videos). It began offering artists funding for their productions in exchange for rights and/or distribution deals, and even opened its own recording facility staffed with a noted producer from Tanzania. Around the same time, the East African subsidiary of MTech Nigeria started expanding its relationships with artists into the areas of management and publishing services as well as production. The move was the brainchild of the subsidiary's Nigerian CEO Ikechukwu Anoke, who ultimately founded his own, Nairobi-based record label, Taurus Musik.

Third-party m-commerce platforms aggregate and distribute music content, sometimes in direct partnership with a mobile service provider. These firms compete not only with each other, but also with m-commerce platforms run by mobile service providers (except on ringback tone platforms, which are the oligopoly of mobile service providers). There has been a great deal of experimentation in the area of $\mathrm{m}$-commerce platforms in African countries, some of which has been fostered by so-called business incubator hubs, organisations that support tech startups with funding (or access to potential investors) as well as other development assistance. The short-lived Ghanaian mobile music streaming platform Streemio, for example, was launched in 2011 with seed funding from Accrabased incubator MEST shortly before being acquired by a larger African company, Spinlet (discussed below) (Thekkepat 2011). And the Kenyan mobile music download platform Mdundo, which arrived at its current freemium subscription model after making news with an innovative plan of using scratchcards to work with artists in building a user base, has been supported since 2012 by Google-backed business incubator $88 \mathrm{mph}$ (Kerongo 2013).

Table 2. Skiza Tunes (Safaricom) digital content intermediaries (as of March 2018).

\begin{tabular}{ll}
\hline Digital Content Firm & \multicolumn{1}{c}{ Content Provided } \\
\hline $\begin{array}{l}\text { Interactive Media Services } \\
\text { Liberty Afrika Technologies } \\
\text { Ltd }\end{array}$ & 'Local and International' \\
MTech Nigeria & 'Nocal Gospel, Local Vernacular, East Africa' \\
Bernsoft Interactive Ltd & 'Reggae, Classical, Dance, Kwaito, Rock, Techno, Country, Sermons and Comedy' \\
Cellulant Kenya Ltd & 'Kenyan Gospel, Kenyan Vernacular/Pop, Wacky Tunes, Inspirational, International' \\
Onfon Media Ltd & 'Kenyan Gospel, Pop, Funny tunes, vernacular, name tunes, corporate, horoscopes, bible \\
& verses, Jokes, prayers, foreign languages, signature names, jobs, sports news, breaking \\
& news, inspiration tnes [sic]' \\
Bluewater Group Ltd & 'SME \& Corporate tunes, Kenyan Gospel, Kenyan Pop, Vernacular, Wacky Tunes' \\
Xpedia Management Ltd & 'Local gospel, Local vernacular, East Africa' \\
Enable-IT Ltd & 'Spoken Word' \\
Spice Vas Kenya Ltd & 'Spice Local, Bongo, International, Football, Islamic, Motivational' \\
User Experience & 'Spoken word, Corporate Tunes' \\
Technologies Ltd & \\
\hline
\end{tabular}


Experimentation in African music m-commerce has entered a new phase, as larger corporations started operations. Such entities are motivated by the potential for growth in music streaming on mobile networks, which is set to pick up as infrastructural and technological improvements lower the cost of such services for African consumers. The year 2013 saw the launch of two large music m-commerce platforms in Africa, Spinlet and Kleek. Spinlet, billed as the African challenger to iTunes, operates as a streaming and music sales platform with a particular focus on mobile network functionality (Koetsier 2013). Kleek, co-founded by Korean tech firm Samsung and French-American media corporation Universal Music (a subsidiary of the French Vivendi Group), offers African content marketed exclusively for Africans, using a dedicated Android app which is exclusively available for Samsung devices (Welch 2013).

A different sort of mobile-based music streaming platform, based on a different sort of corporate arrangement, arrived in Africa in 2014 under the name Tigo Music. This is a collaboration between French music streaming company Deezer and Luxembourg-registered telecom giant Millicom, the latter operating under the brand name Tigo in Chad, DRC, Ghana, Senegal, Rwanda, and Tanzania, in addition to six Latin American countries. Tigo Music offers Tigo network subscribers access to Deezer's sizable international music catalogue plus local music content for a monthly fee. While it has yet to make a significant impact in Africa - at the time of writing, the platform is only available in two African countries, Ghana and Tanzania - Millicom touts its popularity in Latin America as evidence of its potential for success on the African continent (Millicom 2014).

The International Federation of the Phonographic Industry's 2015 Digital Music Report notes a general trend in 'emerging markets' toward 'bundling partnerships' of the sort represented by Tigo Music (IFPI 2015). This makes sense, given the growing demand for internet access across the Global South. Millicom's stated objective in introducing Tigo Music is not only to build a profitable music platform, but also 'to drive data adoption and usage on both mobile and fixed platforms' (Millicom 2015, 22). The complexity of licensing music in African countries does however represent a major obstacle for such initiatives. Licensing music for digital platforms is complex even in the Global North, as intellectual property rights laws and administrative structures are slow to adapt to new technological realities (Wagman 2009). In African countries there is the added problem of what Rotimi Fawole of Spinlet recently referred to as the 'varying level of maturity of intellectual property enforcement in the region' (Kaufman 2016). The 'immaturity' of an IP regime may, of course, enable entrepreneurial activity in music $\mathrm{m}$-commerce, by presenting fewer legal barriers to start-ups. But the march of WTO-driven IP harmonisation means that these enabling factors are likely to be temporary. In Ghana, Kenya, and many other African countries today, developing a digital music platform necessitates a significant investment in resources and personnel solely for dealing with licensing. For its part, Millicom has invested in the creation of its own licensing process, partnering with South Africa-based digital music publisher AfriCori in a 'venture called "Africa Music Rights" ... [which] will fund, acquire and manage music rights across the continent' (Millicom 2014).

\section{Hardware manufacturers}

Mobile phone manufacturers employ multiple strategies to compete in Africa's rapidly growing consumer markets, many of which lead firms toward involvement in local music 
sectors. Take, for example, Korean telecom giant Samsung, recently ranked by Brand Africa as Africa's most admired brand. ${ }^{3}$ Along with offering a special range of devices for the African continent, with features such as 'dual SIM' functionality, and ensuring good customer service across the continent, the company employs local popular music celebrities in African countries for various marketing activities (from television and radio advertisements to meet-and-greets at shopping malls), and actively markets their devices in these countries as music players. This last strategy dovetails nicely with another possible avenue for generating revenue: selling music 'content'. It is not surprising, then, that Samsung has entered into this business in Africa, establishing an Africa-only music streaming service called The Kleek, in partnership with Universal Music Group (Welch 2013).

Samsung is not the only mobile phone manufacturer to mobilise music in their business strategies on the African continent. Finnish manufacturer Nokia launched its first music sales platform for Africa in 2009, and has engaged in a number of music-related marketing activities, including the rap competition 'Don't Break the Beat,' which was first launched in East Africa in 2012 and subsequently brought to West Africa. Nokia researchers even explored possibilities for adding special functionality to mobile phones sold in Africa to facilitate not only music listening, but also music production and distribution (Impio et al. 2009). Meanwhile, in 2013, Ghanaian hardware manufacturer rLG demonstrated an innovative mode of musical marketing, by taking part in a local artist's CD release (Boateng 2013). The company branded all copies of the CD with their logo and distributed the album for free via The Daily Graphic, a popular entertainment newspaper.

\section{Dynamic alignments}

As the foregoing reveals, while music may not be the linchpin of MTT sectors from a financial perspective, it plays a major role in shaping these sectors. Music 'content' that is, music transformed by digital technology into a commodity form that is uniquely aggregable and transportable via mobile telecommunication networks - sets up particular relations between the different types of players in African MTT sectors. Mobile service providers provide data transfer for selling or renting music content, but require both content and hardware to make data bundles useful to consumers; digital content firms provide content, but require data transfer and devices to reach customers; and mobile hardware manufacturers provide devices, but require content and data transfer to make them attractive. This means that the oligonomic concentration of power that characterises music sectors is based less on vertical integration of control over copyrighted material than on the large-scale transformation of artists into 'brands' (Osumare 2014; Shipley 2013).

Technology firms have been involved in music sectors since the dawn of sound recording: manufacturers of radio receivers, vinyl record players, cassette decks, compact disc players, and MP3 playback devices have had significant business interests in music production and sales (see Hesmondhalgh and Meier 2017). African music sectors have been no exception to this; however, the explosion in illicit copying and distribution of recorded music in the 1990s led to a rise in makeshift networks of value creation and extraction (see Larkin 2008) that significantly eroded the mutual interest of technology and music companies on the continent. Thus, while it would be historically incorrect to call it a 'new' phenomenon, the music-MTT convergence nevertheless represents a 
significant break with the political economy of music that had been common across most of Africa since the rise of illicit copying and distribution.

Whereas African music sectors since the 1990s have largely cohered around the transposition of music into a commodity that generates value in the forms of royalties and, more significantly, fame (or celebrity capital, which may be translated to economic capital through celebrity marketing) (Shipley 2013), MTT sectors construct a different set of relations between music and economic value. Digital content firms, for example, extract value from music 'content' by brokering licensing fees between creators and mobile service providers. These firms may be in the business of music sales, but they are not exactly in the business of selling music. They profit not by exchanging music, but by retaining control over popular 'content' and acquiring control over new 'content'. For network service providers, meanwhile, music - even music as 'content' is sometimes merely a condition of exchange, as value is extracted through sales of data bundles that allow users access to the sounds they desire. Hardware manufacturers play a significant role as well, because their devices are necessary tools to playback music, while music increases the appeal of newer and more advanced devices that allow for greater content storage and better playback options. Such capacities also play a part in marketing strategies between hardware manufacturers, keen to associate phones with entertainment functions beyond mere connectivity. At the same time, both network service providers and hardware manufacturers leverage their connections to the music sector by using music and musicians to promote their brands.

The conjunction of the digital music commodity and mobile telecommunications in Africa has thus set the stage for multiple forms of 'musical capitalism' (Born 2013, 51), each of which entails a particular convergence of the music and MTT sectors. We describe these convergences as dynamic alignments, in order to highlight the fact that each bears a distinct trajectory determined by a local ICT infrastructure and regulatory environment as well as the general contingencies of entrepreneurial activity. Figure 1, a revised version of a back-of-the-envelope sketch from our initial notes for this paper, offers an overview of these dynamic alignments, by focusing on three key activities through which they are enacted: Brand Marketing, M-Commerce, and Industry Patronage. While in practice these activities often overlap and bleed into one another, laying them out separately offers a sense of the diversity of actors, interests, and strategies involved in what might otherwise be glossed as a more general 'convergence' of two sectors.

Rather than being an exhaustive analysis of all dynamic alignments, this figure shows the structural mutual reliance of music and MTT sectors. We considered approaching our analysis by working through all these alignments, but that would have made the situation seem too disjunct. In reality, across these dynamic alignments one often finds a concentration of power that lends coherence to the broader convergence they represent. In Kenya, for example, all of the most visible and influential dynamic alignments of the music and MTT sectors have involved a single corporation - Safaricom.

What this suggests is that there is really nothing all that new about the ways in which 'mobilisation' configures relations of power in African music sectors. On the contrary, it would seem that the dynamic alignments of the music and MTT sectors in African countries entail power imbalances that perpetuate, and are perpetuated by, flows of capital through the oligonomic bottlenecks that have long characterised music sectors in the Global North, and to a lesser degree in Africa and other parts of the Global South. 


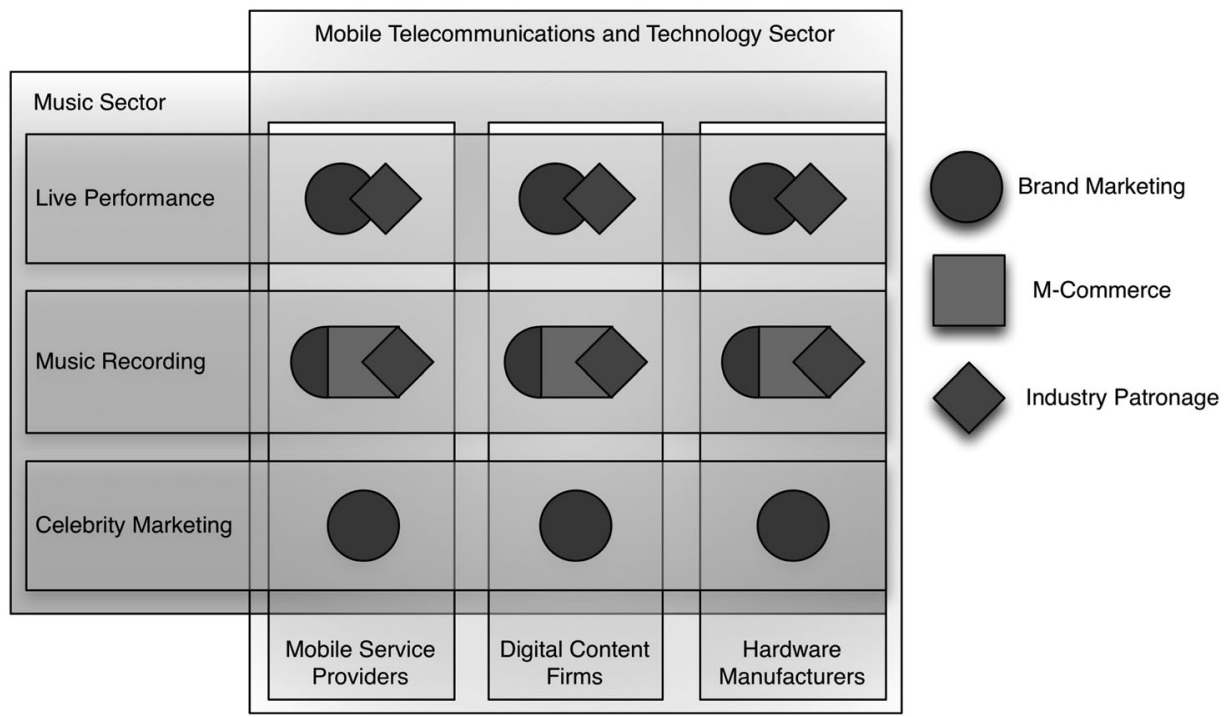

Figure 1. The dynamic alignments of the music and MTT sectors in African countries.

Low royalty yields and limited licensing opportunities make corporate and promotional live events the most lucrative activities in Ghanaian and Kenyan music sectors. The situation is not unique to these countries, of course. Across the African continent, and indeed elsewhere in the world, the value of music increasingly lies in what the attention of audiences is worth to advertisers as corporations look ever more toward 'emotionbased, cultural and lifestyle-oriented marketing strategies' in order to get noticed in the overloaded contemporary mediascape (Meier 2011, 403; see Pier 2015; Shipley 2013).

In this context, MTT and music sectors are increasingly reliant on each other. Mobile service providers face strong competition, limiting their gains on voice and SMS rates (see Supplement 1). They thus seek to increase turnover and profits through data usage, which remains a growth market, while also strengthening their brand identity and brand loyalty in order to retain and strengthen their market position. Meanwhile, digital content firms rely on mobile service providers for the infrastructure and client base they provide. These firms serve as intermediaries - content gatekeepers - and therefore work to secure access to musicians willing to license content and networks able to facilitate the marketing and consumption of this content.

In Kenya, while musicians seem to recognise the oligonomic character of the mobilised music sector, they have opted to embrace digital content firms as organisations that can work with them, much in the same way that musicians have worked with labels as seemingly inevitable partners. This has been particularly true of musicians with established reputations and fan bases, as they have more power to negotiate special deals with these firms. Some Kenyan musicians have even sided with these firms against CMOs, organisations that ostensibly only exist to facilitate musicians' royalty collection, in legal battles over m-commerce royalty distribution. For many musicians, this may seem like the only way to generate income from recorded music sales, as the fully established availability of cheap and easy-to-use copying technologies (cassette tapes and MP3 files) have challenged the artificial scarcity strategies that, for some time, were relatively easy to 
maintain through record sales. The actual revenues through channels provided by digital content firms remain low, as rights holders get a meagre cut - though musicians often use mobile distribution as well as music-based advertisements and endorsement deals as ways to 'launch' new tracks (Klein 2009, 59-78; Meier 2016, 9), bypassing expensive and cumbersome payola practices.

Different strategies exist to sell music content to consumers through mobile telecommunication networks. But a common feature of these strategies is that a limited catalogue of music commodities (song or album downloads, streams, or ringback tone subscriptions) is made available to a large client base at low prices. Whether controlled by record labels or MTT firms, then, African music sectors have introduced (or perhaps re-introduced) their oligonomic character.

\section{Struggling with oligonomy}

On May 20th 2016, The Standard, one of Kenya's major national dailies, published an article on Kenyan artists' struggles to receive fair remuneration for their music from digital content intermediaries. In it, Eunice Njeri, one of the most popular artists on the platform, attests,

I got to see the accounts and how much my songs, which were signed to Liberty Afrika [see Table 2], make and I am not happy ... I was told my song made Sh1 million in a six-month period, when in fact it had made about Sh24 million (Mwaghesha 2016).

Njeri's comment is one among many that have circulated in the Kenyan media that reveal a consciousness of how the convergence of the music and MTT sectors, while perhaps mutually beneficial for the sectors writ large, has reproduced the oligopsonic power relations of the 'old' music economies to the detriment of musicians' livelihoods. How to respond to this situation has been a puzzle for Kenyan artists like Njeri, one that has not been solved - indeed, has perhaps been exacerbated - by the expanded role of collective management organisations in the wake of WTO-driven copyright reforms (Perullo and Eisenberg 2014).

From the earliest days of music m-commerce in Kenya in the first decade of the 2000s, CMOs have been struggling to wrest control from digital content firms. In the beginning, the Music Copyright Society of Kenya (MCSK) - the only Kenyan music CMO in operation before 2006 - established itself as a content aggregator and supplier. But this didn't last long, as digital content firms with greater capacity to offer these services quickly entered into the field. In more recent years, all three of Kenya's registered music CMOs - MCSK, Kenya Association of Music Producers (KAMP), and the Performers Rights Society of Kenya (PRISK) - have pursued negotiation and litigation to gain control over the flow of m-commerce royalties. In May 2016, the High Court of Kenya at Nairobi ruled that royalties should be paid through CMOs, not PRSPs. This was widely seen as a major victory for the CMOs. ${ }^{4}$ But the victory was short lived, as the High Court of Kenya at Malindi reversed the decision only months later, declaring it a violation of artists' constitutionally guaranteed rights to organise with the digital content firms. ${ }^{5}$

Ostensibly, CMOs seek to control m-commerce royalties in order to better regulate and, more importantly, increase payments to artists. At the same time, they aim to secure their institutional role in a music sector that is increasingly reliant on dynamic alignments with 
the MTT sector. At least some Kenyan artists have seen a potential conflict of interest in this situation - one that threatens their own ability to secure the best arrangements for themselves. A few have even sided with digital content firms in court against the CMOs. ${ }^{6}$

In the war between the CMOs and digital content firms, then, Kenyan artists have been like the blades of grass in the old Swahili proverb about who actually gets hurt when two water buffalo fight. But African artists may not be entirely powerless in dealing with MTT firms. After all, MTTs do not simply view artists as generators of 'content'. Writing about hiplife music in Ghana, Jesse Weaver Shipley argues, 'instead of corporations mediating the relationship between consumers and producers, musicians are facilitating the relationship between corporations and publics' (Shipley 2013, 283). Halifu Osumare fleshes out this argument, noting, 'Ghanaian hiplife artists are primed as product endorsers, corporate spokespersons, and symbols of the cosmopolitan ideology and lifestyle that accompany corporate privatization' (Osumare 2014, 189). Taking this analysis directly to the matter at hand, Osumare further argues that mobile service providers, which are the key exponents of corporate encroachment on people's lives across the African continent, need to engage the entire population of countries like Ghana in order to secure solid returns $(2014,197)$. In this context, the strong competition between mobile service providers drives them to pursue aggressive marketing campaigns in which they draw on the popularity of musicians as currency to establish, strengthen, and consolidate their market share in these emerging markets. This gives artists a bit of leverage in their dealings with MTT firms, which a few have used to strike lucrative deals. That said, most individual music artists in Africa find themselves without much leverage in their dealings with MTT firms, especially large mobile service providers like Safaricom. Rather than being bona fide partners for the music economies, she insists, MTTs' motivations are 'only about exploiting culture for financial gain, without genuine respect for music' (Osumare 2014, 205). This bleak picture raises the question of how the seemingly irreversible convergence of African music and MTT sectors can be regulated and enforced to rectify the power imbalances that are exacerbated rather than mitigated by digital innovations.

\section{Conclusion}

The rise of digital media technologies has created new forms of intermediation and interdependence in music sectors worldwide. Our research in Kenya and Ghana suggests that the changes in the African music sectors have some characteristics that do not mirror what has been happening in the West. We contend that the influence of MTTs on music distribution in African contexts warrants empirical and conceptual engagement with the characteristics of the shifts in the African music sectors as a sui generis logic rather than a mutation of a Western model (De Beukelaer 2017; Perullo 2011). This model, we argue, has emerged through the particular constellation of intermediation and interdependence of music sectors and MTTs across Africa.

While in the USA and elsewhere in the Global North 'the computing industry is now one of the key developers of new means of finding, playing, storing, and experiencing music' (Morris 2015, 21), in Africa it is the MTT sector that plays this role. In both cases, music sectors own and control large amounts of content, but require high-tech devices and distribution networks to reach consumers; while device manufacturers and network service providers need music and other content to make their products and services 
attractive (Morris 2015, 21). This mutual reliance creates opportunities for all parties involved, while also opening up new avenues for predatory companies to strive for vertical integration across media.

While inherently unequal, the convergence of music and MTT sectors in African countries fosters new business models and strategies that benefit actors on both sides. New stakeholders with varying degrees of power, influence, and interests have created a volatile context in need of new forms of regulation and legislation. These should account both for the tremendous opportunities that the dynamic alignments of MTT and music sectors bring about, and thoughtfully consider how to mitigate the exploitative relations and oligonomic tendencies.

\section{Notes}

1. The term MP3 also refers to the format, that is, to the 'container technology' that makes (or seems to make) the MP3 music commodity a 'thing' (Sterne 2012, 184).

2. Supplement 1 offers an overview of the activities of mobile service providers in Ghana and Kenya, including data connectivity, subscription rates, and (for Kenya) mobile money transfers.

3. Rankings are available at Brand Africa's interactive website, http://www.brandafrica.net/ Rankings.aspx.

4. The headline by Kenyan daily The Star-'PRSPs Trounced as Court Favours CMOs in Distribution of Skiza Royalties' (Kerongo 2016) — gives a sense of the tenor of the coverage of the ruling.

5. For a brief overview of these cases and links to the rulings, see Matu-Mureithi (2016).

6. Kenyan legal blogger Victor Nzomo registers the irony of the situation thusly:

[O]ne wonders whether the rights holders involved in these law suits understand that it is THEIR royalties and those of other deserving rights holders that are being used to pay the legal bills of the collecting societies to defend these suits (Nzomo 2016).

\section{Acknowledgements}

We presented previous versions of this paper at ECREA (Prague) in November 2016 through the panel Big Tech Meets Culture: The Case of Music chaired by David Hesmondhalgh and Keith Negus, and at the workshop Industries Culturelles et Plateformes Numériques (Cultural Industries and Digital Platforms) hosted by Bertrand Legendre from LABEX ICCA (Industries Culturelles \& Création Artistique) at Maison de la Recherche, Université Sorbonne Paris Cité, November 2016. The paper further benefited from a roundtable we both took part on Music Economies in Sub-Saharan Africa (chaired by Alex Perullo) at the African Studies Association Conference in Washington DC, December 2016. Georgina Born provided valuable input and advice for Andrew Eisenberg's research in Nairobi, which was carried out under the auspices of her European Research Council-funded Advanced Grant Music, Digitization, Mediation: Towards Interdisciplinary Music Studies at the University of Oxford. Ben Morgan provided helpful comments on a draft version of the paper.

\section{Disclosure statement}

No potential conflict of interest was reported by the authors.

\section{Funding}

This work was supported by the European Cultural Foundation (Cultural Policy Research Award (2012)) and FP7 Ideas: European Research Council (249598: Music, Digitization, Mediation: Towards Interdisciplinary Music Studies). 


\section{ORCID}

Christiaan De Beukelaer (iD http://orcid.org/0000-0002-9045-9979

Andrew J. Eisenberg (D) http://orcid.org/0000-0001-6976-7398

\section{References}

BalancingActAfrica. 2011. "Safaricom CEO Bob Collymore on Customer Care, Content and LTE." Youtube. https://www.youtube.com/watch?v=Ve20KaTn2rk.

Beaster-Jones, Jayson. 2014. "Music Piracy, Commodities, and Value: Digital Media in the Indian Marketplace." In The Oxford Handbook of Mobile Music Studies, edited by Sumanth S. Gopinath and Jason Stanyek, 434-455. Oxford Handbooks. New York: Oxford University Press.

Bishop, Jack. 2005. "Building International Empires of Sound: Concentrations of Power and Property in the 'Global' Music Market." Popular Music and Society 28 (4): 443-471. doi:10.1080/ 03007760500158957.

Boateng, Kojo Akoto. 2013. "Becca's 'Time 4 Me' Album Out On May 16; RLG Sponsors Free CD Distribution." Modern Ghana. https://www.modernghana.com/entertainment/21265/beccastime-4-me-album-out-on-may-16-rlg-sponsors-free-c.html.

Born, Georgina. 2013. "Introduction." In Music, Sound and Space: Transformations of Public and Private Experience, edited by Georgina Born, 1-70. Cambridge: Cambridge University Press.

Cellulant Corporation. n.d. "Home." http://www.cellulant.com.

De Beukelaer, Christiaan. 2015. Developing Cultural Industries: Learning from the Palimpsest of Practice. Amsterdam: European Cultural Foundation.

De Beukelaer, Christiaan. 2016. "The Social and Built Infrastructure of Cultural Policy: Between Selective Popular Memory and Future Plans." International Journal of Cultural Policy, October: 114. doi:10.1080/10286632.2016.1248951.

De Beukelaer, Christiaan. 2017. "Toward an 'African' Take on the Cultural and Creative Industries?" Media, Culture \& Society 39 (4): 582-591. doi:10.1177/0163443716664856.

De Beukelaer, Christiaan, and Kim-Marie Spence. 2019. Global Cultural Economy. London: Routledge.

Eckstein, Lars, and Anja Schwarz, eds. 2014. Postcolonial Piracy: Media Distribution and Cultural Production in the Global South. London: Bloomsbury.

Eisenberg, Andrew J. 2012. "M-Commerce and the (Re)Making of the Music Industry in Kenya: Preliminary Notes and Findings." Meetings for the Association for Social Anthropology, New Delhi.

Eisenberg, Andrew J. Forthcoming. "Soundtracks in the Silicon Savannah: Digital Production, Aesthetic Entrepreneurship and the New Recording Industry in Nairobi, Kenya." In Digital Musics: A Global Anthropology, edited by Georgina Born. Cambridge: Cambridge University Press.

Gopinath, Sumanth S. 2013. The Ringtone Dialectic: Economy and Cultural Form. Cambridge, MA: The MIT Press.

Grätz, Tilo. 2013. "New Media Entrepreneurs and Changing Styles of Public Communication in Africa: Introduction." Journal of African Cultural Studies 25 (1): 1-13. doi:10.1080/13696815.2012.751871.

Hesmondhalgh, David. 2013. The Cultural Industries. 3rd ed. London: SAGE.

Hesmondhalgh, David, and Leslie M. Meier. 2017. "What the Digitalisation of Music Tells Us About Capitalism, Culture and the Power of the Information Technology Sector." Information, Communication \& Society, June: 1-16. doi:10.1080/1369118X.2017.1340498.

Holt, Fabian. 2010. "The Economy of Live Music in the Digital Age." European Journal of Cultural Studies 13 (2): 243-261. doi:10.1177/1367549409352277.

IFPI. 2015. Digital Music Report 2015. London: IFPI. http://www.ifpi.org/downloads/Digital-MusicReport-2015.pdf.

Impio, Jussi, Mukeira Masita-Mwangi, Lucy Macharia, Pauline Githinji, and Moses Sitati. 2009. "Need for Richer Features in Addition to Affordability in Entry Mobile Devices." https://www.w3.org/2008/ 10/MW4D_WS/papers/nokia.pdf.

Jenkins, Henry. 2008. Convergence Culture: Where Old and New Media Collide. Updated and with a New Afterword. New York, NY: New York University Press. 
Kaufman, G. 2016. "Sony Music's New Office in Africa Signals a Promising Near-Future for the Continent." Billboard. http://www.billboard.com/articles/business/6890795/sony-music-lagosnigeria-office.

Kerongo, Grace. 2013. "Celebrity Views on the New Music Scratch Cards." The Star. http://www.thestar.co.ke/news/2013/02/13/celebrity.

Kerongo, Grace. 2016. "PRSPs Trounced as Court Favours CMOs in Distribution of Skiza Royalties." The Star. https://www.the-star.co.ke/news/2016/05/11/prsps-trounced-as-court-favours-cmos-indistribution-of-skiza_c1348999.

Klein, Bethany. 2009. As Heard on TV: Popular Music in Advertising. Ashgate Popular and Folk Music Series. Burlington, VT: Ashgate.

Koetsier, John. 2013. "Spinlet, the ITunes of Africa, Hits 650K Subscribers - and Is Targeting 50M Users by 2016." VentureBeat. http://venturebeat.com/2013/09/17/spinlet-the-itunes-of-africahits-650k-subscribers-and-is-targeting-50m-users-by-2016/.

Larkin, Brian. 2008. Signal and Noise: Media, Infrastructure, and Urban Culture in Nigeria. Durham: Duke University Press.

Latour, Bruno. 2005. Reassembling the Social: An Introduction to Actor-Network-Theory. Clarendon Lectures in Management Studies. Oxford: Oxford Univ. Press.

Lee, Kyoung-Joo. 2012. "The Coevolution of IT Innovation and Copyright Institutions: The Development of the Mobile Music Business in Japan and Korea." The Journal of Strategic Information Systems 21 (3): 245-255. doi:10.1016/j.jsis.2012.04.001.

Matu-Mureithi, Louisa. 2016. "Listening to the Skiza Tunes Millions: Section 30a of the Copyright Act Unconstitutional and Role of Collecting Societies." CIPIT Blog, November 22. http://blog.cipit.org/ 2016/11/22/listening-to-the-skiza-tunes-millions-section-30a-of-the-copyright-actunconstitutional-and-role-of-collecting-societies/.

Meier, Leslie M. 2011. "Promotional Ubiquitous Musics: Recording Artists, Brands, and 'Rendering Authenticity'." Popular Music and Society 34 (4): 399-415. doi:10.1080/03007766.2011.601569.

Meier, Leslie M. 2016. Popular Music as Promotion: Music and Branding in the Digital Age. Cambridge, UK: Polity Press.

Millicom. 2014. "Press Release: Millicom Partners With Deezer for Tigo Music in Africa." Accessed January 14, 2018. http://www.millicom.com/media/1984/deezerafricaprfinal.pdf.

Millicom. 2015. Annual Report 2015: @Millicom Driving \#Digitalaccess for 25 Years. Luxembourg: Millicom. http://www.millicom.com/media/4562100/full-annual-report-millicom-2015.pdf.

Morcom, Anna, and Patrick Neveling, eds. 2015. Music and Capitalism. Guest-Edited Feature. FocaalBlog. http://www.focaalblog.com/features/music-and-capitalism.

Morris, Jeremy Wade. 2015. Selling Digital Music, Formatting Culture. Oakland, CA: University of California Press.

Mwaghesha, Mkala. 2016. "Musical Wars: Artistes Fight over Distribution of Skiza Tunes Pay." Standard Digital News. http://www.sde.co.ke/article/2000202468/musical-wars-artistes-fightover-distribution-of-skiza-tunes-pay.

Nzomo, Victor Buziba. 2016. "Music, Money and Middle Men: Changing Dynamics Between Collecting Societies, Rights Holders and the Public." CIPIT Blog, January 22. http://blog.cipit.org/ 2016/01/22/music-money-and-middle-men-changing-dynamics-between-collecting-societiesrights-holders-and-the-public/\#more-3506.

Osumare, Halifu. 2014. "Becoming a 'Society of the Spectacle': Ghanaian Hiplife Music and Corporate Recolonization." Popular Music and Society 37 (2): 187-209. doi:10.1080/03007766.2012.747262.

Perullo, Alex. 2011. Live from Dar Es Salaam: Popular Music and Tanzania's Music Economy. Bloomington, IN: Indiana University Press.

Perullo, Alex, and Andrew J. Eisenberg. 2014. "Musical Property Rights Regimes in Tanzania and Kenya After TRIPs." In Sage Handbook of Intellectual Property, edited by M. David and D. Halbert, 148-163. Thousand Oaks, CA: SAGE.

Pier, David G. 2015. "Ugandan Music in the Marketing Era: The Branded Arena." http://search. ebscohost.com/login.aspx?direct $=$ true\&scope $=$ site \&db=nlebk\&db=nlabk\&AN=1091430.

Röschenthaler, Ute, and Mamadou Diawara, eds. 2016. Copyright Africa: How Intellectual Property, Media and Markets Transform Immaterial Cultural Goods. Canon Pyon: Sean Kingston Publishing. 
Safaricom. 2017. "Safaricom Skiza Tunes." https://www.safaricom.co.ke/personal/get-more/ entertainment/skiza.

Shipley, Jesse Weaver. 2012. "The Birth of Ghanaian Hiplife: Urban Style, Black Thought, Proverbial Speech." In Hip Hop Africa: New African Music in a Globalizing World, edited by Eric S. Charry, 29-58. African Expressive Cultures. Bloomington, IN: Indiana University Press.

Shipley, Jesse Weaver. 2013. Living the Hiplife: Celebrity and Entrepreneurship in Ghanaian Popular Music. Durham, NC: Duke University Press.

Skinner, Ryan Thomas. 2014. "Money Trouble in an African Art World: Copyright, Piracy and the Politics of Culture in Postcolonial Mali." In Postcolonial Piracy: Media Distribution and Cultural Production in the Global South, edited by Lars Eckstein and Anja Schwarz, 243-271. London: Bloomsbury.

Sterne, Jonathan. 2012. MP3: The Meaning of a Format. Sign, Storage, Transmission. Durham: Duke University Press.

Stobart, Henry. 2010. "Rampant Reproduction and Digital Democracy: Shifting Landscapes of Music Production and 'Piracy' in Bolivia." Ethnomusicology Forum 19 (1): 27-56. doi:10.1080/ 17411911003669616.

Street, John, Dave Laing, and Simone Schroff. 2016. "Regulating for Creativity and Cultural Diversity: The Case of Collective Management Organisations and the Music Industry." International Journal of Cultural Policy, May: 1-19. doi:10.1080/10286632.2016.1178733.

Taylor, Timothy Dean. 2012. The Sounds of Capitalism: Advertising, Music, and the Conquest of Culture. Chicago: The University of Chicago Press.

Taylor, Timothy Dean. 2015. Music and Capitalism: A History of the Present. Chicago, IL: Chicago University Press.

Thekkepat, Shiva Kumar. 2011. "A Leg-Up With Start-Ups in Ghana." Gulf News, April 15. http:// gulfnews.com/culture/education/a-leg.

Théberge, Paul. 1997. Any Sound You Can Imagine: Making Music/Consuming Technology. Music/ Culture. Hanover, NH: Wesleyan University Press : University Press of New England.

Wagman, Shane. 2009. "I Want My Mp3: Legal and Policy Barriers to a Legitimate Digital Music Marketplace." Journal of Intellectual Property Law 17 (95): 95-120.

Welch, Chris. 2013. "Universal Music, Samsung Launch Kleek Music Streaming Service in Africa." The Verge. http://www.theverge.com/2013/3/14/4103286/universal-music-samsung-the-kleek-musicstreaming-africa. 


\title{
Mobilising African music: how mobile telecommunications and technology firms are transforming African music sectors
}

\author{
Christiaan De Beukelaer (10 ${ }^{\mathrm{a}}$ and Andrew J. Eisenberg (i) ${ }^{\mathrm{b}}$
}

${ }^{a}$ School of Culture and Communication, University of Melbourne, Melbourne, Australia; ${ }^{b}$ Division of Arts and Humanities, New York University Abu Dhabi, United Arab Emirates

\section{Supplement 1: Mobile Service Providers in Ghana and Kenya}

Mobile service providers connect vast swaths of the populations of Ghana and Kenya, and internet use has ballooned in these countries within the past decade as a result (see Table 1). While the excessively high percentages of mobile phone connections per capita shown in Table 2 and Table 3 result in part from subscribers using multiple networks to take advantage of free or discounted intra-network calls and texts, and promotional data bundles, they are indicative of a large and growing user base. The companies that supply mobile services in these countries are diverse, as a result of the liberalisation of telecom services under WTO free trade agreements (Singh 2002). To some extent, Western-owned multinationals remain important in the new and aggressive mobile telecom markets (see the shares of UK, France, and Luxemburg telecoms in Table 2 and Table 3). But players from Nigeria, India, and South Africa account for vast shares of the Kenyan and Ghanaian markets (see Table 2 and Table 3). In Ghana (Table 2), the major players are MTN (South Africa) and Vodafone (UK), with respectively $48.47 \%$ and $21.91 \%$ of the market. As there are more mobile phone connections than there are people, they cover a greater share of the population than their market share suggests; $64.63 \%$ and $29.21 \%$ respectively.

The competitive environment for mobile voice and text communication has driven mobile service providers to embrace the sale of data and so-called 'value added services'. Data use, both in terms of number of subscribers and the amount of data consumed, forms a primary growth segment for mobile service providers, resulting in vast markets for telecom operators that sell data bundles (ranging on average from 100 megabytes to 5 gigabytes). Table 4 and Table 5 show remaining potential for further market penetration in this area, which promises to drive further competition and innovation. Value added services form a less significant growth segment for mobile service providers, with the notable exception of mobile money transfer solutions such as Safaricom's M-Pesa.

Launched in 2007, M-Pesa ( $M$ for mobile, pesa means 'cash' in Swahili) is a relatively lowtech, SMS-based system that facilitates person-to-person money transfers via mobile phones. Kenya's leading mobile network operator, Safaricom, developed M-Pesa in response to people trading airtime (phone credit) as a form of cash payment (Hughes and Lonie 2007). In the second quarter of 2016, the total value of M-Pesa transactions exceeded 957 billion Kenyan Shillings (Ksh), or 9 billion US Dollars (see Table 6).

CONTACT Christiaan De Beukelaer Christiaan.DeBeukelaer@unimelb.edu.au $\Theta$ School of Culture and Communication, University of Melbourne, Melbourne, Australia

(1) This supplement accompanies the article that can be accessed here: https://doi.org/10.1080/13696815.2018.1546569. 
Table 1. Telecommunications Connectivity in Ghana and Kenya (2015) as share of the overall population

\begin{tabular}{lrrrr}
\hline & \multicolumn{2}{c}{ Ghana } & & \multicolumn{2}{c}{ Kenya } \\
\cline { 2 - 5 } & 2010 & 2015 & & 2010 \\
\hline Mobile-cellular telephone subscriptions & $71.82 \%$ & $129.74 \%$ & $61.03 \%$ & $80.68 \%$ \\
Percentage of individuals using the Internet & $7.80 \%$ & $23.48 \%$ & $14.00 \%$ & $46.62 \%$ \\
Fixed-telephone subscriptions & $1.15 \%$ & $1.02 \%$ & $0.93 \%$ & $0.18 \%$ \\
Fixed-broadband subscriptions & $0.21 \%$ & $0.28 \%$ & $0.02 \%$ & $0.28 \%$ \\
\hline
\end{tabular}

Source: International Telecommunication Union (2018)

Table 2. Mobile Service Providers in Ghana (September 2016)

\begin{tabular}{|c|c|c|c|c|c|}
\hline Network & Parent Company & Parent Company Base & $\begin{array}{l}\text { Subscription Base } \\
\text { in Ghana }\end{array}$ & $\begin{array}{l}\text { Market } \\
\text { Share }\end{array}$ & $\begin{array}{l}\text { Population } \\
\text { Share }\end{array}$ \\
\hline MTN & MTN Group (97.7\%) & Johannesburg, South Africa & $18.05 \mathrm{~m}$ & $48.47 \%$ & $64.63 \%$ \\
\hline $\begin{array}{l}\text { Vodafone } \\
\text { Ghana }\end{array}$ & Vodafone $(70 \%)$ & $\begin{array}{l}\text { London / Newbury, United } \\
\text { Kingdom }\end{array}$ & $8.16 \mathrm{~m}$ & $21.91 \%$ & $29.21 \%$ \\
\hline Airtel (ex Zain) & Bharti Airtel (75\%) & New Delhi, India & $4.70 \mathrm{~m}$ & $12.61 \%$ & $12.61 \%$ \\
\hline Tigo & Millicom (100\%) & Luxembourg, Luxembourg & $5.40 \mathrm{~m}$ & $14.51 \%$ & $19.35 \%$ \\
\hline Glo & $\begin{array}{l}\text { Globacom Limited } \\
(100 \%)\end{array}$ & Lagos, Nigeria & $0.83 \mathrm{~m}$ & $2.22 \%$ & $2.97 \%$ \\
\hline \multirow{2}{*}{$\begin{array}{l}\text { Expresso } \\
\text { Telecom }\end{array}$} & Sudatel (75\% stake) & Khartoum, Sudan & $0.10 \mathrm{~m}$ & $0.28 \%$ & $0.37 \%$ \\
\hline & & Total & $37.40 \mathrm{~m}$ & $100 \%$ & $\begin{array}{c}133.35 \% \\
\text { (of } 27.93 \mathrm{~m})^{1}\end{array}$ \\
\hline
\end{tabular}

Source: National Communications Authority (2016)

${ }^{1}$ Estimate provided in the National Communications Authority 2016 dataset.

Table 3. Mobile Telecom Operators in Kenya (June 2016)

\begin{tabular}{|c|c|c|c|c|c|}
\hline Network & Parent Company & $\begin{array}{c}\text { Parent Company } \\
\text { Base }\end{array}$ & $\begin{array}{l}\text { Subscription Base } \\
\text { in Kenya }\end{array}$ & $\begin{array}{l}\text { Market } \\
\text { Share }\end{array}$ & $\begin{array}{l}\text { Population } \\
\text { Share }\end{array}$ \\
\hline Safaricom & $\begin{array}{l}\text { Vodafone (40\%), Public float } \\
\text { (60\%) }\end{array}$ & $\begin{array}{l}\text { London / Newbury, } \\
\text { United Kingdom }\end{array}$ & $25.91 \mathrm{~m}$ & $65.21 \%$ & $58.69 \%$ \\
\hline Airtel (ex Zain) & Bharti Airtel (80\%) & New Delhi, India & $6.59 \mathrm{~m}$ & $15.56 \%$ & $14.91 \%$ \\
\hline $\begin{array}{l}\text { Orange } \\
\text { (Telekom } \\
\text { Kenya) }\end{array}$ & $\begin{array}{l}\text { Orange S.A. (ex France Telecom) } \\
(70 \%) \text { and Kenyan } \\
\text { Government }(30 \%)\end{array}$ & Paris, France & $4.80 \mathrm{~m}$ & $13.17 \%$ & $11.85 \%$ \\
\hline \multirow[t]{2}{*}{ Equitel } & $\begin{array}{l}\text { Finserve Africa Limited (Equity } \\
\text { Group Holdings Limited) }\end{array}$ & Nairobi, Kenya & $2.02 \mathrm{~m}$ & $5.07 \%$ & $4.56 \%$ \\
\hline & & Total & $39.78 m$ & $100 \%$ & $\begin{array}{c}90.01 \% \\
\text { (of } 42.2 \mathrm{~m})^{1}\end{array}$ \\
\hline
\end{tabular}

Source: Data adapted from Communications Authority of Kenya (2016)

${ }^{1}$ Estimate provided by the Kenya National Bureau of Statistics in their 2016 Economic Survey. This number is used by the Kenyan Communications Authority in their calculations of industry trends. 
Table 4. Mobile Data Subscription Rates in Ghana (Sept 2016)

\begin{tabular}{|c|c|c|c|c|c|}
\hline Network & Parent Company & Parent Company Base & $\begin{array}{c}\text { Subscription Base in } \\
\text { Ghana }(12 / 2013)\end{array}$ & $\begin{array}{l}\text { Market } \\
\text { Share }\end{array}$ & $\begin{array}{l}\text { Population } \\
\text { Share }\end{array}$ \\
\hline MTN & $\begin{array}{l}\text { MTN Group } \\
(97.7 \%)\end{array}$ & $\begin{array}{l}\text { Johannesburg, South } \\
\text { Africa }\end{array}$ & $9.75 \mathrm{~m}$ & $50.42 \%$ & $34.90 \%$ \\
\hline $\begin{array}{l}\text { Vodafone } \\
\text { Ghana }\end{array}$ & Vodafone (70\%) & $\begin{array}{l}\text { London / Newbury, } \\
\text { United Kingdom }\end{array}$ & $3.31 \mathrm{~m}$ & $17.15 \%$ & $11.87 \%$ \\
\hline $\begin{array}{l}\text { Airtel (ex } \\
\text { Zain) }\end{array}$ & Bharti Airtel (75\%) & New Delhi, India & $3.09 \mathrm{~m}$ & $16.00 \%$ & $11.07 \%$ \\
\hline Tigo & Millicom (100\%) & $\begin{array}{l}\text { Luxembourg, } \\
\text { Luxembourg }\end{array}$ & $2.87 \mathrm{~m}$ & $14.86 \%$ & $10.29 \%$ \\
\hline Glo & $\begin{array}{l}\text { Globacom } \\
\text { Limited (100\%) }\end{array}$ & Lagos, Nigeria & $0.27 \mathrm{~m}$ & $1.37 \%$ & $0.95 \%$ \\
\hline \multirow[t]{2}{*}{$\begin{array}{l}\text { Expresso } \\
\text { Telecom }\end{array}$} & $\begin{array}{l}\text { Sudatel }(75 \% \\
\text { stake) }\end{array}$ & Khartoum, Sudan & $0.04 \mathrm{~m}$ & $0.21 \%$ & $0.14 \%$ \\
\hline & & Total & $19.33 \mathrm{~m}$ & $100 \%$ & $\begin{array}{c}69.22 \% \\
\text { (of } 27.93 \mathrm{~m})^{1}\end{array}$ \\
\hline
\end{tabular}

Source: National Communications Authority (2016)

${ }^{1}$ Estimate provided in the National Communications Authority (2016) dataset.

Table 5. Mobile Data Subscription Rates in Kenya (June 2016)

\begin{tabular}{|c|c|c|c|c|c|}
\hline Network & Parent Company & $\begin{array}{l}\text { Parent Company } \\
\text { Base }\end{array}$ & $\begin{array}{l}\text { Subscription Base } \\
\text { in Kenya }\end{array}$ & $\begin{array}{l}\text { Market } \\
\text { Share }^{1}\end{array}$ & $\begin{array}{l}\text { Population } \\
\text { Share }\end{array}$ \\
\hline Safaricom & $\begin{array}{l}\text { Vodafone (40\%), Public float } \\
\quad(60 \%)\end{array}$ & $\begin{array}{l}\text { London / } \\
\text { Newbury, United } \\
\text { Kingdom }\end{array}$ & $24.06 \mathrm{~m}$ & $63.8 \%$ & $54.4 \%$ \\
\hline Airtel (ex Zain) & Bharti Airtel (80\%) & New Delhi, India & $7.05 \mathrm{~m}$ & $18.7 \%$ & $16.0 \%$ \\
\hline $\begin{array}{l}\text { Orange } \\
\text { (Telekom } \\
\text { Kenya) }\end{array}$ & $\begin{array}{l}\text { Orange S.A. (ex France Telecom) } \\
(70 \%) \text { and Kenyan } \\
\text { Government (30\%) }\end{array}$ & Paris, France & $3.77 \mathrm{~m}$ & $10.0 \%$ & $8.5 \%$ \\
\hline \multirow[t]{2}{*}{ Equitel } & $\begin{array}{l}\text { Finserve Africa Limited (Equity } \\
\text { Group Holdings Limited) }\end{array}$ & Nairobi, Kenya & $2.83 \mathrm{~m}$ & $7.5 \%$ & $6.4 \%$ \\
\hline & & Total & $39.78 m$ & $100 \%$ & 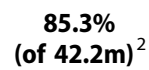 \\
\hline
\end{tabular}

Source: Communications Authority of Kenya (2016)

${ }^{1}$ The Kenyan Communications Authority do not provide more detailed or precise data. We have calculated the subscription base and population share based on these percentages.

${ }^{2}$ Estimate provided by the Kenya National Bureau of Statistics in their 2016 Economic Survey (Kenya National Bureau of Statistics 2017). This number is used by the Kenyan Communications Authority in their calculations of industry trends. 
Table 6. Mobile Money Transfers in Kenya (June 2016)

\begin{tabular}{|c|c|c|c|c|c|c|c|}
\hline Service & Agents & Subscriptions & Number of Transactions & Value of Transactions & $\begin{array}{c}\text { Mobile Commerce } \\
\text { Transactions }\end{array}$ & $\begin{array}{l}\text { Value of Mobile } \\
\text { Commerce (Ksh) }\end{array}$ & $\begin{array}{c}\text { Person to Person } \\
\text { Transfers (Ksh) } \\
\end{array}$ \\
\hline M-Pesa (Safaricom) & 107,936 & $7.12 \mathrm{~m}$ & $307.09 \mathrm{~m}$ & $807,087.00 \mathrm{~m}$ & $168.51 \mathrm{~m}$ & $323,188.94 m$ & $366,025.97 m$ \\
\hline Equitel & 0 & $1.86 \mathrm{~m}$ & $59.91 \mathrm{~m}$ & $138,525.61 \mathrm{~m}$ & $49.95 \mathrm{~m}$ & $70,085.12 m$ & $63,305.23 m$ \\
\hline Airtel Money & 13,944 & $4.85 \mathrm{~m}$ & $8.86 \mathrm{~m}$ & $10,897.10 \mathrm{~m}$ & $8.86 \mathrm{~m}$ & $10,897.10 \mathrm{~m}$ & $5.983 .02 \mathrm{~m}$ \\
\hline Mobikash & 16,733 & $1.77 \mathrm{~m}$ & $2.07 \mathrm{~m}$ & $373.54 \mathrm{~m}$ & 25,107 & $24.52 \mathrm{~m}$ & $118.75 \mathrm{~m}$ \\
\hline Orange Money & 18,518 & $0.19 \mathrm{~m}$ & 33,000 & $199.44 m$ & 1,388 & $0.80 \mathrm{~m}$ & $4.29 m$ \\
\hline Tanganza & 1,596 & $0.50 \mathrm{~m}$ & - & - & - & - & - \\
\hline Total & 158,727 & $26.30 \mathrm{~m}$ & $375.87 m$ & $957,074.69 \mathrm{~m}$ & $227.36 m$ & $404,196.49 m$ & $429,454.64 m$ \\
\hline
\end{tabular}

Source: Communications Authority of Kenya (2016) 


\section{References}

Communications Authority of Kenya. 2016. "Quarterly Sector Statistics Report Fouth Quarter for the Financial Year 2015-2016 (April-June 2016)." Communications Authority of Kenya.

Hughes, Nick, and Susie Lonie. 2007. "M-PESA: Mobile Money for the 'Unbanked' Turning Cellphones into 24-Hour Tellers in Kenya." Innovations: Technology, Governance, Globalization 2 (1-2): 63-81. doi:10.1162/itgg.2007.2.1-2.63.

International Telecommunication Union. 2018. "Country ICT Data." International Telecommunication Union. https://www.itu.int/en/ITU-D/Statistics/Pages/stat/default.aspx.

Kenya National Bureau of Statistics. 2017. "Economic Survey 2016." Kenya National Bureau of Statistics. https://www.knbs.or.ke/download/economic-survey-2016/.

National Communications Authoruity. 2016. "Telecom Voice Subscription Statistics." National Communications Authority. https://nca.org.gh/industry-data-2/market-share-statistics-2/voice-2/.

Singh, J. P. 2002. "Negotiating Regime Change: The Weak, the Strong, and the WTO Telecom Accord." In Information Technologies and Global Politics: The Changing Scope of Power and Governance, edited by James N. Rosenau and J. P. Singh, 239-274. SUNY Series in Global Politics. Albany, NY: State University of New York Press. 